\title{
Irigaray and Hölderlin on the Relation Between Nature and Culture
}

\author{
Alison Stone \\ Institute for Environment, Philosophy, and Public Policy, Lancaster University, Lancaster, \\ LA14YG, UK, a.stone@lancaster.ac.uk
}

Abstract. This paper explores the compatibility of Luce Irigaray's recent insistence on the need to revalue nature, and to recognise culture's natural roots, with her earlier advocacy of social transformation towards a culture of sexual difference. Prima facie, there is tension between Irigaray's political imperatives, for if culture really is continuous with nature, this implies that our existing, non-sexuate, culture is naturally grounded and unchallengeable. To dissolve this tension, Irigaray must conceive culture as having self-transformative agency without positioning culture as active vis-à-vis an inert and passive nature. I argue that Irigaray achieves this by conceiving culture to arise from a division internal to nature. She derives this idea from Hölderlin, who claims that nature originally divides itself into subjects and objects, and from Heidegger, who maintains that nature inflicts an originary violence upon itself. Critically reworking Hölderlin and Heidegger, Irigaray argues that male nature tends to turn against itself to generate an anti-natural, ecologically destructive, culture. She argues, however, that this tendency can be redirected and alleviated by the very cultural resources which male nature generates in dividing itself. Irigaray thus develops a unique way to advocate social change while recognising nature's profound impact and influence upon culture.

This paper offers an interpretation of Luce Irigaray's later philosophical reflections on the relation between nature and culture. ${ }^{1}$ Irigaray is now widely recognised as a thinker of change, who seeks social transformation towards a culture of sexual difference, within which 
femininity and masculinity would share equivalent value and symbolic and civil status. ${ }^{2}$ In her recent work, Irigaray also urges cultural change to recognise the value and fundamental importance of nature, and to recognise how profoundly culture is invariably shaped by, and dependent upon, nature. She insists that 'it is from the natural that we should start over in order to refound reason' and that thinking must 'understand its natural roots and resources' ${ }^{3}$ Yet there appears to be some tension between Irigaray's political imperatives, for if every culture has natural roots, then our current non-sexuate culture must be naturally grounded and therefore, presumably, resistant to change. To understand Irigaray's later thought, and to appreciate the continuities within her political and philosophical thinking as a whole, it is important to explore how her recent attention to humanity's dependence upon nature builds on, rather than compromises, her earlier insistence on the necessity and possibility of cultural change.

This question is not narrowly relevant to scholars of Irigaray's thought, but has importance for broader debates in feminist philosophy. Contemporary feminist thinkers generally agree that western culture and society have a pervasive tendency to devalue and denigrate nature relative to culture and to align nature symbolically with femininity, which becomes equally devalued. Thus, most feminist thinkers concur that women's situation can be improved only through symbolic and social change to recognise culture's dependence upon, and continuity with, nature. However, if culture truly is continuous with nature, this implies that there must be some natural basis for current, patriarchal, culture, and hence that this culture cannot readily be changed. This undesirable implication pushes feminists back to affirming culture's independence of, or underdetermination by, nature; yet that affirmation threatens to perpetuate women's symbolic devaluation, insofar as women are aligned with nature. Seeking to escape this dilemma, many feminist theorists contest the culture/nature 
antithesis, suggesting that, although culture has a natural basis, nature is always already cultural too.

For instance, Elizabeth Grosz argues that feminists should neither ignore nature nor treat it as a blank slate for cultural inscriptions, but examine how culture and nature intertwine. ${ }^{4}$ She suggests that nature sets limits to cultural possibilities, and that nature consists of multiple tendencies and potentialities, which cultures can develop in variable ways (VB, 187, 191). Grosz takes etching as a model for this process of cultural development, since etching must 'take into account the specificities of the materials ... being inscribed and their concrete effects in the kind of text produced' (VB, 191). Yet Grosz goes on to deny that nature has any determinate character prior to cultural development. She claims that the natural limits to culture are malleable, because nature's potentialities are not given prior to culture but produced through cultural processes (VB, 188, 227). Ultimately, then, Grosz believes that culture interacts only with a nature that is already a cultural artefact. In this way, she continues to privilege culture over nature, identifying culture as the ontologically basic reality, from which nature derives. ${ }^{5}$ A more ambiguous assessment of nature's intertwining with culture is provided by Moira Gatens, who argues that there are determinate natural tendencies and forces upon which culture builds. ${ }^{6}$ Although, for Gatens, these tendencies are culturally pliable, she suggests that the culture which modifies natural tendencies is always given determinate direction by natural forces in their initial form. Gatens' approach promises to allow a more genuine interweaving of nature with culture, yet prompts several questions. How far must culture be independent of natural tendencies in order to modify them? If culture is independent of those tendencies, then how far do they ever really direct it?

Irigaray's later philosophy provides answers to these questions, suggesting that culture has agency vis-à-vis nature only because culture arises from an internal division 
within nature itself. She supports this suggestion with a unique and complex conception of the nature/culture relationship which arises from her engagement with Heidegger and, ultimately, with the German Romantic poet Friedrich Hölderlin. In tracing how Irigaray elaborates this conception, I will begin by examining her critique of patriarchal culture's hostility to nature in Thinking the Difference (1989). Irigaray argues that this culture stems from men's naturally destructive tendencies, and, to explain how patriarchal culture can be both anti-natural and rooted in nature, she suggests that this culture emerges in a movement whereby nature turns against itself. As I hope to show, Irigaray derives this intriguing idea from Hölderlin's view that nature originally divides itself (which Heidegger rewrites as the view that nature inflicts violence upon itself, although here I shall focus principally on Hölderlin, as the originator of this entire line of thought concerning nature). Modifying Hölderlin, Irigaray argues that male nature tends to turn against itself, but that this tendency can be overcome through the very cultural resources which (male) nature generates in its selfdivision. ${ }^{7}$ Thus, Irigaray advocates cultural change to transform nature's originally selfdestructive tendencies, but since she conceives culture as natural, she avoids reproducing the masculinism of the traditional culture/nature hierarchy. Her later thought can thus make a valuable contribution to feminist reflection on nature and culture by understanding cultural change as compatible with renewed recognition of, and esteem for, nature.

\section{Nature and culture in Irigaray's Thinking the Difference}

Irigaray does not explicitly set out her novel conception of the nature/culture relationship, but it is implicit in several of her later texts, most notably the essay 'A Chance to Live' in Thinking the Difference and the chapter of To Be Two (1994) entitled 'Between Us, a Fabricated World'. Whereas her discussion of nature and culture in the latter text is mediated through readings of Heidegger, Hölderlin, and Sophocles, the earlier text is couched in a 
more popular style (originally presented as a talk to the Italian Communist Party). Yet, in addition to popularising Irigaray's earlier ideas, Thinking the Difference outlines a unique approach to the relation between nature and culture. Irigaray's burgeoning interest in this theme stems from her concern at the Chernobyl disaster of 1986, which galvanised her to reflect on the ecological dangers posed by a culture that is (in some sense) severed from nature.

Irigaray begins by pointing to a widespread cultural unease which, she thinks, has crystallised around Chernobyl. Prior to Chernobyl, one could imagine that nature would regulate and alleviate the ill-effects of human activities. But, Irigaray rather oddly claims, 'at Chernobyl, nature turned out to be a vehicle of greater destruction than any war' (TD, 3). She adds that this destruction stemmed from a 'combination of ... artificial pollution and natural phenomena: hails, storms, even sun' (4). These claims are puzzling: surely Chernobyl was a thoroughly human-made disaster? Irigaray seems to believe that the destructiveness of the event was so great - that 'the cultural disorder into which we are being drawn ... has become [so] intolerable' - as to draw nature itself into the same destructive cycle that characterises human culture. Ultimately, then, Irigaray regards Chernobyl as reflecting the deeper-lying problem that western culture is fundamentally destructive, towards nature particularly. Irigaray maintains that this destructiveness reflects the fact that western culture has been created by and for men. ${ }^{8}$ She writes: 'This warlike method of organizing society is not selfevident. Its origin is patriarchal. It is sexuate [sexuée]' (5) - or, as she later states, 'society ... has certain characteristics which pass for universal but are in fact attributable to the sex of the people that compose it' (17).

Irigaray goes on to claim that this masculine or patriarchal culture evinces a preoccupation with death and destruction while persistently neglecting, and failing to reflect upon, the primary importance for all human beings of their birth and dependency upon their 
mothers in early infancy. ${ }^{9}$ She then enumerates some further features of patriarchal culture its suppression of mother-daughter relationships ${ }^{10}$ and its tendency to deny women legal rights - but the fundamental task generated by her opening analysis is to explain in what way the destructiveness of western culture reflects its specifically masculine character. Her explanation unfolds in two stages.

Firstly, Irigaray suggests that patriarchal culture has its roots in the particular difficulties of male infants in negotiating separation from their mothers (separation in the dual sense of birth and of the gradual process of becoming independent and forming a separate sense of self). According to Irigaray, this process of separation is inescapably painful for all infants - she speaks of the 'the losses and scars involved in the separations from that first home ... The wound we cannot heal, and cannot cure, is the cutting of the umbilical cord' (SG, 16). But, for boys, this separation is especially painful, because boys are overwhelmingly aware of their sexual difference from their mothers. In contrast, girls experience themselves as being of the same sex as their mothers - as Irigaray puts it: 'Woman ... immediately becomes a subject in relation to another subject who is the same as she: her mother' (TD, 19). Consequently, girls face the rather different difficulty of learning to combine their shared sexual identity with a resilient sense of individual difference from their mothers. ${ }^{11}$ Boys, for their part, have an immediate experience of sexual difference, which is painful because it makes the loss of their mothers much more profound. Irigaray clarifies this later on in Thinking the Difference: 'the son does not know how to situate himself in regard to the person who engendered him with no possible reciprocity. He cannot conceive in himself ... The situation is different for the daughter, who is potentially mother' (TD, 110-111).

Irigaray develops the same point more fully in an interview for Hypatia: 
The relation of the little boy to his mother is different from the little girl's relation. The little boy, in order to situate himself vis-à-vis the mother, must have a strategy, ... because he finds himself in an extremely difficult situation. He's a little boy. He has come out of a woman who's different from him. He himself will never be able to engender, to give birth. He is therefore in a space of unfathomable mystery. He must invent a strategy to keep himself from being submerged, engulfed. For the little girl it's entirely different. She's a little woman born of another woman. She is able to engender like her mother (JLI, 107-108).

Girls, then, can adapt to losing their mothers because they experience themselves as having the same corporeal abilities as their mothers, which ensures some continuity. Lacking this experience, boys must adopt a variety of coping strategies. Chief among these is to deny or disavow ever being dependent upon, or closely imbricated with, their mothers. This denial forces boys to disavow, in turn, their own corporeality, which bears testimony to dependency and finitude. Irigaray calls this whole strategy the 'murder' of the mother - not (usually) a literal murder, but an attitude of denying the mother's significance, and even existence, at a symbolic level. ${ }^{12}$ Underneath this murderous attitude lingers a fantasy of fusion with and proximity to the mother, a fantasy which boys/men never relinquish (precisely because they never acknowledge it), and which surreptitiously invades and blights all their relations with women.

Irigaray's account of male difficulties in separating from the mother might be thought to rely on the implausible view that boys cannot tolerate separation from their mothers because they know that they will never be able to give birth (whereas girls know that they will be able to). This is implausible both because some girls will never be able to give birth and because young children are reasonably thought to lack knowledge of their future 
reproductive abilities. However, Irigaray fundamentally understands the ability (and inability) to give birth as functions of women's (and men's) distinctive rhythms, the distinctive temporal patterns which govern the development of their experience and capacities (TD, 114115). ${ }^{13}$ Thus, the sexual difference that boys experience is the difference between their rhythm and that of their mothers, where boys' particular rhythm structures and pervades their experience without them having any (conceptual) knowledge of what this rhythm is or signifies. If there genuinely are differences between sexuate rhythms as Irigaray believes, then it is plausible to think that boys will experience their own rhythm as different from that of their mothers, and that this experience must aggravate existing difficulties with separation. Moreover, boys'/men's resultant strategy of symbolically murdering the mother can be expected to engender a destructive culture because, much of the time, boys/men will seek to negate and erase whatever is corporeal and natural. Boys/men will let this destructiveness persist unchecked because they remain trapped in a fantasy according to which the natural, corporeal, and (by association) maternal remains ever-present and indestructible (precisely that collective fantasy which Irigaray sees as threatened by the severity of the Chernobyl disaster).

Thinking the Difference offers an additional account of how western cultural destructiveness is masculine: this culture is rooted in male sexuality, which, Irigaray claims, obeys a different pattern to female sexuality, that of 'tension, release and return to homoeostasis' (TD, 21). She maintains that this sexuality impels men to engage in destructive modes of behaviour that seek to raise tensions to breaking point. Irigaray finds this reflected, especially, in modern technology, which (in its incessant noise, for example) intrudes disrespectfully upon the natural rhythms of human bodies. Notably, Irigaray's analysis of male sexuality implies that it generates practices and technologies which operate detrimentally to other elements of male embodiment. It appears that, for Irigaray, male 
corporeality turns against itself, some aspects of this corporeality perpetrating violence upon others.

Potentially problematically, Irigaray appears to assume that male sexuality has a determinate character independently of any cultural mediation. We should bear in mind, though, that Irigaray again regards male sexuality as a function of men's distinctive rhythm. In this way, she understands sexual difference not primarily as biological but as a difference in men's and women's being - where being is not an entity, but the process of emergence of abilities, forms of experience, and anatomical structures, a process which differs between the sexes in respect of its temporal rhythm. ${ }^{14}$ For Irigaray, this difference in sexuate being exists naturally. Following the later Heidegger, Irigaray thinks of being both as the event or process through which entities emerge, and as ultimately identical with nature (reconceived according to its original Greek definition as physis). ${ }^{15}$ Irigaray does, therefore, believe in natural differences between men and women, existing prior to any cultural mediation. But this is not mere naïvety on her part, and involves no uncritical acceptance of the discourse of biology. Rather, Irigaray believes in natural differences according to a distinctively philosophical reconception of nature. This philosophical reconception of nature informs her understanding of the nature/culture relationship in Thinking the Difference, which we can now begin to draw out.

Irigaray believes that male nature has generated a culture which opposes itself to nature, including to female bodies and to male bodies qua natural. There is, then, a part of nature - the male sex - which turns against itself. Western culture arises in this turning of (the male part of) nature against itself, thereby acquiring the enduring form of an anti-natural, ecologically damaging, culture. Irigaray's derivation of key features of western culture from male nature thus forms part of a careful attempt to avoid reifying culture as something independent of nature, and to understand culture, instead, as an internal torsion within the 
natural. This intriguing reconceptualisation of culture - and, concomitantly, of nature as selfopposing - remains only implicit in Irigaray's analysis of destructive culture in Thinking the Difference, but it becomes relatively explicit in To Be Two.

In the latter text, Irigaray opens her consideration of nature and culture by quoting the choral song from Sophocles' tragedy Antigone which begins (in the translation she uses):

'There is much that is uncanny, but nothing that surpasses man in uncanniness'. Heidegger is Irigaray's primary interlocutor here: he discusses this chorus in his 1935 lecture course Introduction to Metaphysics, to which Irigaray is critically responding. ${ }^{16}$ However, in the background to her response is a further level of engagement with Friedrich Hölderlin, whose thinking about humanity centrally informs Heidegger's discussion of Sophocles. Although Hölderlin is not, in general, an obvious interlocutor of Irigaray's, references to him occur sporadically throughout her oeuvre; in This Sex Which Is Not One, she proposed to teach a history of readings of Antigone, including that of Hölderlin, who translated this drama. ${ }^{17}$ Moreover, Irigaray is aware of Heidegger's debt to Hölderlin, so that her response to Heidegger inevitably encompasses Hölderlin as well. To understand Irigaray’s consideration of the nature/culture relation in To Be Two, then, we must first gain an overview of Hölderlin's speculations on this topic. ${ }^{18}$ We can then explore how these speculations influence Heidegger, and how Irigaray eventually responds to both thinkers.

\section{Hölderlin, nature, and the human}

Hölderlin's thinking about nature arose in the context of early German Romanticism, which aspired to overcome the modern disenchantment of nature by producing art which would reinfuse nature with 'beauty, magic and mystery'. ${ }^{19}$ Hölderlin became increasingly critical of this project of re-enchanting nature through art, which he came to find anthropocentric, presupposing the same separation between humanity and nature that it purported to 
overcome. Hölderlin's increasingly critical attitude to Romanticism reveals his deepening conviction that humanity's very separation from nature arises through a natural process humanity being merely the site where nature turns against itself. This conviction of Hölderlin's becomes crucial for Heidegger and, in turn, Irigaray.

Hölderlin's thinking about humanity's status within nature represents the progressive working out of his early theoretical reflections on nature, especially those contained in his crucial early fragment 'Judgement and Being'. Here Hölderlin argues that all consciousness involves the subject relating to objects via judgement, through which it distinguishes these objects from itself. For Hölderlin, consciousness as a subject-object relation necessarily presupposes a prior unity of subject and object, a unity which is no mere synthesis but an absolute unification which precedes any distinction. This unity is, he states, 'Being [which] expresses the combination of subject and object. Where subject and object are directly, not just partially, united, ... there and nowhere else can there be talk of being as such, ${ }^{20}$ However, this 'blessed unity, being' cannot be known. ${ }^{21}$ We cannot be conscious of being, because all consciousness requires experience of objects from which we differentiate ourselves as subjects - a differentiation which is absent within being. Insofar as we are conscious, judging subjects, being is lost to us. Now, unitary being, Hölderlin also maintains, is nature. He equates original being with nature because he relies on the ancient Greek understanding of nature as physis, that which 'loves to hide'. ${ }^{22}$ Because being is always disappearing, receding behind the separation between objects and subjects, being can be said to 'love to hide', and so can be identified with nature. As J. M. Bernstein sums up, 'nature as the ground of the human cannot appear because it would have to be judged, but if judged, then it is already in a state of dispersion'. ${ }^{23}$ We can experience nature only as the realm of objects standing over against us, but cannot experience that prior nature which is united with us; as conscious, we have always already lost that originary nature. 
Through this analysis, Hölderlin identifies the disenchantment of nature as an inescapable consequence of reflection, where reflectiveness itself is an ineluctable concomitant of human consciousness. As his character Hyperion laments, 'an instant of reflection hurls me down. I reflect, and ... the world in its eternal oneness is gone; nature closes her arms, and I stand like an alien before her and do not understand her' ${ }^{24}$ For Hölderlin, our conscious reflectiveness as humans marks us out as distinctively cultural, historical, beings, who are inherently estranged from nature. Despite the fact that nature is therefore unknowable for us, Hölderlin believes that we retain some sense of it as our basis and origin, for which we are always nostalgic. Consciousness, separation, and reflection presuppose an original unity of which we necessarily retain some vestigial awareness. This awareness impels us to strive to reunite with nature - 'To reunite ourselves with nature, with a unique infinite totality, is the goal of all our strivings' ${ }^{25}$

From the later 1790s onwards, Hölderlin developed his thoughts on human separation from nature by theorising ancient Greek tragedy. 'The significance of tragedies' (1802) conceives the tragic hero as compelled to reunite with nature: Empedocles, for example, sought unity with nature and eventually flung himself into Mount Etna to achieve it. However, in drafting and redrafting his own tragedy The Death of Empedocles, Hölderlin came to identify two possible responses to separation from nature. The first, Greek, response - that of Empedocles - is to dissolve the self and die. The second response is the 'Hesperian', which defines western Europe after the decline of classical Greece, and which accepts the living death of separation from nature. ${ }^{26}$ Hölderlin came to see the Hesperian response as more appropriate, finding the Greek attitude hubristic, premised on an inflated assessment of humanity's status within the cosmos. Hölderlin never systematically argues for the Hesperian response, but we can reconstruct why it becomes appropriate given the logic of his earlier thinking concerning nature. 
If humanity is originally wholly one with nature, then their separation cannot arise from any activity on the part of humanity just as such. This separation must arise from nature, with which humanity is initially united. Nature must divide itself - into humanity on one side, and an objectified derivative of itself on the other. To construe ourselves, human beings, as responsible for this division is to presume our capacity to act independently of nature as a whole - when in fact, Hölderlin says, 'all the ... streams of human activity ... have their source in nature'. ${ }^{27}$ From Hölderlin's perspective, then, it must be inappropriate for humanity to attempt to overcome separation (whether through suicide or artistic projects of reenchantment). To suppose that humanity can overcome separation is to assume that humanity can act independently of nature (so as to oppose the self-division which nature has initiated). Even though all striving for unity is a striving to dissolve one's humanity, this striving remains, ultimately, premised upon anthropocentric assumptions. In fact, according to Hölderlin's thinking, we have become separated from nature by its power alone, so it is not within our power to undo separation. ${ }^{28}$ The appropriately modest response is to recognise our dependence and hence to endure separation - to wait, patiently, until nature may change its mode of being. Humanity, Hölderlin increasingly comes to believe, must undergo the suffering of division from nature.

Having previously positioned humanity as distinctly non- or anti-natural, Hölderlin increasingly draws out how nature persists within the non-naturalness of humanity. For Hölderlin, humanity is non-natural just because it is the place where nature divides itself, splits within itself. The human condition of opposition to nature is inflicted upon humanity by nature. Hölderlin thus understands humanity as naturally non-natural, reciprocally conceiving nature as self-opposing, self-dividing. This understanding of humanity may be characterised as thoroughly non-anthropocentric, in that it traces even humanity's anti- 
natural, cultural, proclivities back to (self-dividing) nature. This thoroughly nonanthropocentric view of humanity becomes decisive for Heidegger and Irigaray.

\section{Irigaray's response to Hölderlin and Heidegger}

In his Introduction to Metaphysics, Heidegger comments on the choral ode to Sophocles' Antigone while discussing the essence of the human. He aims to return to the original, ancient Greek, definition of human being, a poetic definition which he finds expressed in the writings of Heraclitus, Parmenides, and in Antigone. Heidegger takes as Antigone's central definition that humanity is to deinotaton, which he translates as the 'most uncanny' (Unheimlichste). Humanity is singularly uncanny because it is the point at which nature (as physis) divides against itself. Although Heidegger does not mention Hölderlin at this point in the lecture course, Hölderlin's understanding of the human is evidently in the background - especially since Heidegger refers earlier to Hölderlin's unsurpassed understanding of 'the great age of

Greek beginnings' ${ }^{29}$ Nonetheless, Heidegger departs from Hölderlin in giving central place to humanity's violence (Gewalt), as we will see.

Heidegger begins by exploring the Greek concept of deinon, translated as uncanny or terrible. Firstly, being or physis is uncanny because it is irreducible to beings (it is the event of their emergence which, preceding all beings, cannot be properly said to 'be'). Heidegger also describes being in its emergent, eruptive, character as violent, as the 'overwhelming sway’ (überwältigende Walten). Humanity derives from physis and, as such, is violent too. However, humanity is distinguished in being violent towards the rest of the beings that emerge physically: humanity (as Sophocles tells us) intrudes violently into sea and earth, forcibly tames and exploits animals, and, above all, masters beings as a whole by imposing intelligibility upon them. Humanity, then, is the place at which the violence of physis turns upon itself, which makes humanity the most uncanny. As Susan Schoenbohm explains 
Heidegger's thought: 'As human, the violent is a power of physis, ... indeed, the power of physis, which uses violence against itself; that the overwhelming sway turns against itself characterises the power of physis ${ }^{30}$ Whereas Hölderlin focused on humanity's separation from nature without defining this separation as per se violent, Heidegger foregrounds the violence both of physis and of humanity towards other beings. He envisions humanity as destined to actively struggle with other beings (primarily through the intellectual and poetic struggle to wrest intelligibility from them).

Heidegger also stresses that humanity is destined to misunderstand its violent powers as manifesting its independent agency (when in fact, these powers are really powers of physis). In 'his' very resourcefulness and violence, the human being cannot but mistake 'the power which pervades him, which alone enables him to be a man' (IM, 156) for a power that 'he' has somehow brought about through his own resources. But because, in fact, humanity's power derives from physis, humanity is destined to be defeated by physis in its struggle against it. Each human being, then, must die; through death, there occurs a closing up of the 'breach' within being that humanity represents (124). However, Heidegger suggests the possibility of embracing one's death, by actively wrestling against nature while knowing that the struggle is doomed. Whereas Hölderlin counselled acceptance of our limits, Heidegger urges violence towards the beings of nature; he cannot at this point concede the worth of any non-violent ways of relating to other physical beings. ${ }^{31}$

Heidegger's emphasis on violence enables Irigaray to connect Hölderlin's conception of humanity's place in nature with her analysis of western destructiveness and its specifically masculine character. 'Between Us, a Fabricated World' largely adopts Irigaray’s well-known mimetic style, beginning by quoting the Sophoclean ode and then paraphrasing portions of Heidegger's commentary upon it. Irigaray writes, 'Man upsets the rhythm of natural growth. He plows the earth and obliges it to produce by force what it does not yield on its own ... 
Man imposes a yoke upon the life that unfolds in itself but whose foundations he does not inhabit' (TBT, 69). Man is the inquiétante being who breaks out of the nature to which he was originally enslaved and dominates it, instituting a second, cultural and historical, world (70). Following Heidegger, Irigaray adds that man becomes 'exiled' and 'estranged' from his being in this cultural world, inevitably coming to identify himself as the creator of this entire sphere, when, 'in fact, he has only imitated the strength of the universe which surrounds him ... man's mastery resembles the natural strength with which he wishes to measure himself'. His strength and violence are really that of nature, operating through him.

Besides paraphrasing Heidegger, Irigaray distances herself subtly from him (and, indirectly, from Hölderlin) by highlighting the sexually differentiated nature of the humanity through whom nature enacts violence upon itself. At first, she uses Heidegger's language of 'man' mimetically, but, as her essay unfolds, she marks increasingly firmly that male humanity is in question, not humans per se. Thus, she states that the violence of culture 'can be explained beginning from a masculine subjectivity' (TBT, 76). She also writes that:

The feminine is not called to carry out the task of constructing a world which is similar to man's: a violent, uncanny world, which exists through the domination of nature ... To ... cultivate herself without violence or power over what surrounds her - all of these correspond more to feminine being. (72)

Irigaray suggests that men are violent due to their special difficulty in accepting sexual difference: 'man chooses to ignore this irreducible difference ... Is this not because he feels foreign to this life which lives without him, this life which reproduces itself ... ?' (70) Or, as she states later on, man's violence is 'probably related to man's relationship with the one who generates him: he will never generate in himself and must fabricate things outside of himself, in order to separate himself from the mother; he must manufacture externally, while she generates internally' (76). For Irigaray (drawing on her earlier analysis in Thinking the 
Difference), it is men's difficulty in accepting sexual difference which leads them to turn against women, and, simultaneously, against the nature of which they themselves are partas when men engineer technologies which damage their own nature.

While Irigaray agrees with Hölderlin and Heidegger that nature turns against itself, she holds that only males mediate this turn. Man's, but not woman's, nature is to be uncanny and violent. Through men's activities, women become embroiled in a non-natural mode of life that is fundamentally alien to them. Evidently, Irigaray can only identify men as the sole mediators of nature's violence because she believes in an original sexual differentiation within nature (against which men, as one pole of this differentiation, react). This contrasts with Hölderlin's view of nature as original, absolute, unity. Believing in an originary differentiation, Irigaray understands male violence to consist, typically, in the forcible imposition of sameness upon women and other natural beings. Hölderlin, on the other hand, conceives humans as separated from nature insofar as their power of judgement leads them to divide, analyse, and reflectively partition natural beings. But for Irigaray, Hölderlin's conception of nature as primordially unitary instantiates the same disavowal of sexual difference which underpins male hostility to nature. By denying originary difference, Hölderlin's account of nature becomes complicit with the very separation from nature that he wishes to question. ${ }^{32}$

Irigaray's belief in an originary sexual differentiation makes nature's turning against itself considerably less mysterious than it is for Hölderlin. The opening up of a division within primordial unity must necessarily be a mysterious event, since this unity itself contains no grounds for diremption. In contrast, Irigaray's analyses in To Be Two and Thinking the Difference make it quite intelligible why the male pole of a pre-existing differentiation should turn, reactively, against (the rest of) nature. One might object that there remains a mystery as to how nature originally becomes sexually dual: that is, that Irigaray has simply pushed the 
mysterious event of division back to reside in the movement whereby sexual difference naturally emerges. However, although Irigaray does regard sexual difference as mysterious, she locates its mystery precisely in its irreducibility to any prior unity (TBT, 111).

To Be Two deepens Irigaray's earlier analysis of male destructiveness, understanding the male sex as the place where nature enacts violence upon itself. Male violence - and patriarchal culture, with its separation from and hostility to nature - derive from a nature understood, philosophically, both as sexually differentiated and as effecting a violent turn against itself. Irigaray does not, then, regard patriarchal culture as natural in the sense of grounding it, uncritically, in biology. By drawing from Hölderlin and Heidegger an unusual conception of nature as self-dividing, she avoids naïve biologism, but simultaneously avoids reifying culture as a separate, independent, sphere. Yet, in arguing that destructive culture arises naturally, must not Irigaray construe this culture as unchangeable? Intriguingly, given her emphasis upon culture's natural roots, she insists throughout To Be Two that patriarchal culture can be changed. Let us explore this dimension of her thought.

\section{The place of nature in the culture of sexual difference}

Irigaray stresses that western violence represents only one possible cultural direction, an alternative having been taken in 'the Far East'. More specifically, she suggests that men could learn to cultivate respect for the sexually different other, and for other natural beings. Men could practise 'self-mastery' (TBT, 172) - self-restraint in the face of their desire to act violently and deny difference. Yet how is this attitudinal change possible, if - as Irigaray has maintained - men just are the site through which nature turns upon itself? Irigaray explains

that: 'The fact that [man's] impulses, inclinations and desires are violent does not necessarily mean that this is an inherent part of masculine being, but that violence can come from an historical construction' (71). Likewise, in Thinking the Difference, she maintains that men's 
destructiveness stems from the absence of a 'sexual culture, a (partially dialectical) pattern of cultural relations between the genders [genres]' (TD, 17). But if, after all, patriarchal culture explains masculine psychical difficulties, then what explains the formation and tenacity of patriarchal culture?

Irigaray's apparently contradictory statements regarding the contributions of nature and culture to male violence can be reconciled if she believes that men have only a natural tendency to violence. If so, then male violence is not inevitable, because men's destructive tendency will be activated or exercised only if a set of appropriate conditions is met. Moreover, contextual factors invariably affect how any tendency exercises itself, so that its manifestation is always socially and culturally mediated, in complex, unpredictable, ways. Thus, Irigaray need not envisage a linear causal relationship between masculine violence and a destructive culture. Rather, men's violent tendencies will become activated in the absence of a sexuate culture, an absence which leaves men without resources to comprehend and acclimatise to sexual difference. The little boy finds himself in a space of unfathomable mystery only because his culture, which is non-sexuate, deprives him of ways to make sense of his mother's difference from himself. If femininity were instead recognised as an independent identity, and masculinity were recognised as a correspondingly specific identity with virtues and values of its own, then the difficulty of sexual difference would become negotiable.

Yet how can culture, which is only the effect of nature's tendency to turn against itself, ever affect the natural tendency from which it results? Irigaray's answer is that culture arises as something genuinely non-natural through nature's turn against itself, a nonnaturalness that enables culture to act back upon the nature that sustains it. Here Irigaray denies that she is falling back onto the traditional idea that culture is independent of nature for her, the anti-naturalness of culture itself arises naturally. Moreover, she also insists that a 
sexuate culture would not oppose nature's self-opposing tendencies altogether (which would, after all, be self-contradictory, for then this culture would effectively cancel itself out). Rather, a sexuate culture would cultivate natural tendencies - transforming them and orienting them in a new, relatively benign, direction. In particular, this culture would redirect men's oppositional tendencies - their 'negativity' - against themselves, so as to install within them a permanent check against their own destructiveness, and a stimulant to respect for the other and for nature. ${ }^{33}$

For Irigaray, then, the violent, anti-natural, character of western culture has arisen through our own - cultural - failure to redirect nature's tendency to turn against itself. A sexuate culture could counteract this tendency and push it towards a new respect for alterity. Whereas Hölderlin counsels us to wait patiently for possible change in nature's own mode of being, Irigaray urges that we - as human, cultural, beings - should intervene to reorientate nature's self-destructive tendency. In these divergent recommendations, Hölderlin and Irigaray might at first sight appear to occupy the two poles of the dilemma with which I opened this paper, over whether or not we should affirm that culture has natural foundations. Hölderlin denies culture any independence of nature, but consequently espouses quietism. Irigaray advocates cultural change, but would therefore seem obliged to grant culture some independent agency with respect to nature. Yet she avoids making that move: although she allows culture the agency to transform and cultivate nature, she does so without conceiving culture as independent of nature, instead reconceiving it as dependent on nature for its agency. This agency arises naturally, through internal division within nature. Irigaray treats nature as the ontologically basic element within the culture/nature dyad, distancing herself from the masculinist tradition which typically devalues nature, depicting it as secondary to the cultural, spiritual, realm. Irigaray thereby succeeds in combining a consistent refusal of the masculinist nature/culture hierarchy with advocacy of cultural change. Her thought thus 
dissolves feminist philosophy's dilemma, opening up a way for feminists to combine support for cultural change with commitment to securing renewed recognition and esteem for nature. In highlighting these unique strengths of Irigaray's philosophy of sexual difference, I do not mean to suggest that it is without problems. Her conception of the nature/culture relation relies on her belief in natural sexual difference, which she regards as fundamentally real in a way that racial and ethnic differences are not (ILTY, 47). Her understanding of natural sexual difference is also, arguably, heteronormative, implying a natural attraction between the two sexes. ${ }^{34}$ Nonetheless, I believe that these problems could be most productively addressed by starting from and transforming, rather than rejecting, Irigaray's fruitful conception of the nature/culture relation. I hope that this paper has shown that this conception is sufficiently original and important to deserve such further elaboration and transformation.

\section{Endnotes}

${ }^{1}$ Irigaray's conception of nature is receiving growing attention from feminist scholars: see Stacy Keltner, 'The Ethics of Air: Technology and the Question of Sexual Difference', Philosophy Today 2001 (Supp.),53-65; Ann V. Murphy, 'The Enigma of the Natural in Irigaray', Philosophy Today 2001 (Supp.), 75-82.

${ }^{2}$ On Irigaray as a philosopher of change, see especially Alison Martin, 'Luce Irigaray and the Culture of Difference', Theory, Culture and Society 20: 3 (2003), 1-12.

${ }^{3}$ I Love to You, trans. Alison Martin (London: Routledge, 1996), 37; Sexes and Genealogies, trans. Gillian C. Gill (Ithaca: Cornell University Press, 1993), 86. Repeatedly cited works by Irigaray are hereafter cited parenthetically using the following abbreviations: SG Sexes and Genealogies, trans. Gillian C. Gill (Ithaca: Cornell University Press, 1993) 
TD Thinking the Difference, trans. Karin Montin (London: Athlone, 1994)

JLI “"Je - Luce Irigaray”: A Meeting with Luce Irigaray’, interview with Elizabeth Hirsch and Gary A. Olson, in Hypatia 10: 2 (1995), 93-114

ILTY I Love to You, trans. Alison Martin (London: Routledge, 1996)

TBT To Be Two, trans. Monique M. Rhodes and Marco F. Cocito-Monoc (London: Athlone, 2000)

${ }^{4}$ Grosz, Volatile Bodies (Bloomington: Indiana University Press, 1994), 21. Hereafter cited parenthetically as VB.

${ }^{5}$ For this criticism of Grosz, see also Terri Field, 'Is the Body Essential for Ecofeminism?', Organization and Environment 13: 1 (2000), 44.

${ }^{6}$ See Gatens, Imaginary Bodies (London: Routledge, 1996), 9, 69-73.

${ }^{7}$ Throughout I will speak indifferently of men or males, and of masculine or male culture, eliding the distinction between biological sex and social gender, which does not register for Irigaray in French. As will become clearer in this paper, her avoidance of this distinction also has deeper grounds in her philosophical understanding of culture as natural.

${ }^{8}$ As Margaret Whitford observes, Irigaray insistently links the conceptual pair creation/destruction to the sexual pair female/male; see Whitford, 'Irigaray, Utopia and the Death Drive', in Engaging with Irigaray, ed. Carolyn Burke, Naomi Schor, and Margaret Whitford (New York: Columbia University Press, 1994), 382.

${ }^{9}$ Other feminist philosophers have explored western culture's (masculine) preoccupation with death: see Adriana Cavarero, In Spite of Plato, trans. Serena Anderlini-D’Onofrio and Áine O’Healy (Cambridge: Polity Press, 1995). 
${ }^{10}$ On Irigaray's account of how patriarchy erases mother/daughter relationships and female genealogies, see Margaret Whitford, Luce Irigaray: Philosophy in the Feminine (London: Routledge, 1990), ch. 4.

${ }^{11}$ Irigaray differs from Nancy Chodorow, who claims that girls have difficulty separating from their mothers because mothers treat their daughters like themselves, constructing in the daughters the sense of a common gender identity; meanwhile, mothers construct their sons as different by pushing them away. Chodorow's claims reflect a theoretical understanding of gender identity as acquired through socialisation. By contrast, Irigaray's approach is phenomenological, beginning from the subject's experience of sexed identity. See Chodorow, The Reproduction of Mothering (California: University of California Press, 1978).

${ }^{12}$ See Irigaray, 'Women-Mothers, the Silent Substratum of the Social Order', in The Irigaray Reader, ed. Margaret Whitford (Oxford: Blackwell, 1991), 47.

${ }^{13}$ On the importance of the concept of rhythm for Irigaray's understanding of sexual difference, see Alison Stone, ‘The Sex of Nature: A Reinterpretation of Irigaray’s Metaphysics and Political Thought', Hypatia 18: 3 (2003), 60-84.

${ }^{14}$ On Irigaray's view of sexual difference as a difference in being - an ontological, not ontic, difference - see, inter alia, JLI, 110. On rhythm as a structuring process irreducible to any kind of entity - and so not reducible to a static form or essence - see Elaine Miller, The Vegetative Soul (Albany: SUNY Press, 2002), 47-48. I am skating over some extremely complex and controversial aspects of Irigaray's thought here, fuller consideration of which exceeds the scope of this paper.

${ }^{15}$ On Heidegger's - and Hölderlin's - conception of nature as physis, see below, esp. 11.

${ }^{16}$ Irigaray discusses Heidegger in many places, most conspicuously The Forgetting of Air in Martin Heidegger, trans. Mary Beth Mader (Austin: University of Texas Press, 1999), but I 
will confine myself solely to her response in 'Between Us, a Fabricated World'. For a survey of literature on Heidegger and Irigaray, see Patricia Huntingdon's introduction to Feminist Interpretations of Martin Heidegger, ed. Nancy J. Holland and Patricia Huntingdon (Pennsylvania: Penn State Press, 2001), 6-9, 15-18.

${ }^{17}$ Irigaray, This Sex Which Is Not One, trans. Catherine Porter (Ithaca: Cornell University Press, 1985), 167. Irigaray again refers to Hölderlin (in relation to Antigone) in her 'Introduction' to her recent book Between East and West, trans. Stephen Pluháček (New York: Columbia University Press, 2002), 19. To a considerable extent, this 'Introduction' reprises the argument of 'Between Us, a Fabricated World', making explicit Irigaray's background engagement with Hölderlin in the latter.

${ }^{18}$ Inevitably, this overview must be simplified (notably omitting any account of Hölderlin on poetry or the divine); I aim to present the details of Hölderlin's texts just sufficiently to reconstruct in them a coherent line of thinking regarding the status of humanity within nature. ${ }^{19}$ Frederick Beiser, 'German Romanticism', in The Routledge Encyclopaedia of Philosophy, ed. Edward Craig (London and New York: Routledge, 1998). For the classic statement of this early German Romantic programme of re-enchantment, see Friedrich Schlegel, 'Dialogue on Poetry', trans. Ernst Behler and Roman Struc, in German Romantic Criticism, ed. A. Leslie Willson (New York: Continuum, 1982), 100, 106-107.

${ }^{20}$ Hölderlin, 'Being Judgement Possibility' (usually translated as 'Judgement and Being'), in Classic and Romantic German Aesthetics, ed. J. M. Bernstein (Cambridge: Cambridge University Press, 2003), p. 191.

${ }^{21}$ Preface to penultimate draft of Hyperion, in Friedrich Hölderlin: Sämtliche Werke und Briefe, ed. Günter Mieth (2 vols.; Munich: Carl Hanser Verlag, 1970), vol. 1, 558. 
${ }^{22}$ As Françoise Dastur comments, 'Nowhere does Hölderlin quote Heraclitus' fragment saying that "nature likes to dissimulate itself", but his understanding of nature is as near as it can be in modern times to the pre-Socratics' approach to physis'; see Dastur, 'Tragedy and Speculation', in Philosophy and Tragedy, ed. Miguel de Beistegui and Simon Sparks (London: Routledge, 2000), 87.

${ }^{23}$ Bernstein, introduction to Classic and Romantic German Aesthetics, xxvi.

${ }^{24}$ Hölderlin, Hyperion and Selected Poems, ed. Eric L. Santner (New York: Continuum, 1990), 4.

${ }^{25}$ Preface to penultimate draft of Hyperion in Sämtliche Werke und Briefe, vol. 1, 558.

${ }^{26}$ Hölderlin writes that 'in his [Empedocles'] opponent ... the subjective takes on more the passive shape of suffering, endurance, firmness' (Essays and Letters, 61; on the concept of the 'Hesperian', see 114).

${ }^{27}$ Hölderlin, letter to his brother, 4 June 1799, in Sämtliche Werke und Briefe, vol. 2, 820. ${ }^{28}$ Perhaps Hölderlin's greatest statement of this thought is in his poem 'As on a holiday...', where the poet attempts to precipitate a reconciliation with nature on his own initiative and is cast down, humiliated, by the gods for this hubris; see Hölderlin, Poems and Fragments, trans. Michael Hamburger (London: Anvil Press, 1994), 399.

${ }^{29}$ Heidegger, Introduction to Metaphysics, trans. Ralph Manheim (New Haven: Yale University Press, 1959), 126. It is worth recalling that in 1934/5, Heidegger lectured on Hölderlin's hymns 'Germania' and 'The Rhine': his thinking in Introduction to Metaphysics is intimately connected with his appropriation of Hölderlin's poetic thought.

${ }^{30}$ Susan Schoenbohm, 'Heidegger's Interpretation of Phusis in Introduction to Metaphysics', in A Companion to Heidegger's Introduction to Metaphysics, ed. Richard Polt and Gregory Fried (New Haven: Yale University Press, 2001), 157. 
${ }^{31}$ Influenced by the earlier Irigaray, Huntingdon critically analyses Heidegger's masculinist imagery, in which manly creators must appropriate and harness the powers of feminine physis; see her Ecstatic Subjects, Utopia, and Recognition (Albany: SUNY Press, 1998), ch. 2).

${ }^{32}$ Irigaray seems to want to extend this criticism to Heidegger, claiming, for example, that he ignores how air punctuates and introduces duality into physis (see 'From The Forgetting of Air to To Be Two', in Feminist Interpretations of Martin Heidegger, esp. 310-311).

${ }^{33}$ See Irigaray, The Way of Love, trans. Stephen Pluháček (London: Continuum, 2002), 78.

${ }^{34}$ For some discussion of the later Irigaray's heteronormativity, see Pheng Cheah and Elizabeth Grosz, ‘Of being-two: Introduction’ Diacritics 28: 1 (1998), 3-18; Ofelia Schutte, 'A critique of normative heterosexuality: Identity, embodiment, and sexual difference in Beauvoir and Irigaray', Hypatia 12: 1 (1997), 40-62. 